\title{
PENGARUH KOMPENSASI DAN DISIPLIN KERJA TERHADAP KINERJA KARYAWAN PADA PT. CANDANA PUTRA NUSANTARA
}

\author{
Prayogi Abd. Jalil \\ Department of Management FEB UMM \\ E-mail: prayogiabduljalil14@gmail.com
}

\begin{abstract}
This study aims at describing and analyzing the effect of compensation and work discipline toward employees' work performance especially the production division of PT. Candana Putra Nusantara. This study was conducted by distributing questionnaire to 100 respondents by using Total Sampling Method. The analysis technique applied was range scale and double linear regression. The result of the study shows 1) Employees' work performance is considered high, compensation is considered medium, and work discipline is medium. 2) Partially, according to the t-test, the compensation had significant effect toward employees', performance. 3) Work discipline had significant effect toward employees' performance. 4) the f-test result showed that compensation and work discipline had significant effect toward employees' work performance, and 5) Compensation as a stronger variable in affecting employees' work performance. Company is suggested to pay attention more on the compensation by providing salary based on Minimum Wage of Probolinggo and improving work discipline especially toward the company's regulation.
\end{abstract}

Keywords: compensation, work discipline, employees' work performance

\section{PENDAHULUAN}

Dalam persaingan dunia bisnis yang semakin hari semakin membutuhkan inovasi, pelaku bisnis dituntut untuk terus melakukan inovasi. Agar usahanya tetap bertahan dan hidup. Perusahaan pada umumnya didirikan dengan tujuan dapat melangsungkan hidupnya dan untuk memperoleh keuntungan yang maksimal. Agar tujuan yang telah ditetapkan tercapai maka diperlukan perencanaan dan pengelolaan sumber daya manusia sebaik-baiknya. Perencanaan sumber daya manusia harus mempunyai tujuan yang berdasarkan kepentingan individu, organisasi, dan kepentingan nasional. Tujuan perencanaan sumber daya manusia yang ada untuk kebutuhan perusahaan pada masa datang ( Mangkunegara 2006 : 7).

Sumber daya manusia mempunyai fungsi yang penting dalam pencapaian produktivitas kerja oleh karena itu tenaga kerja perlu dipicu kinerjanya, mengingat bahwa sumber daya manusialah yang mengatur atau mengelola sumber -sumber daya lainnya. Tercapainya tujuan perusahaan tidak hanya tergantung dari peralatan modern, sarana dan prasarana yang lengkap, tetapi justru lebih 
tergantung pada manusia yang melaksanakan pekerjaan tersebut.

Sumber daya manusia mempunyai fungsi yang penting dalam pencapaian produktivitas kerja oleh karena itu tenaga kerja perlu dipicu kinerjanya, mengingat bahwa sumber daya manusialah yang mengatur atau mengelola sumber -sumber daya lainnya. Dengan demikian berhasil tidaknya suatu proses pekerjaan lebih banyak tergantung pada unsur manusianya.

Kinerja merupakan hasil kerja secara kualitas dan kuantitas yang dicapai oleh seorang pegawai dalam melaksanakan tugasnya sesuai dengan tanggung jawab yang diberikan kepadanya (Mangkunegara, 2007 : 67). Keberhasilan suatu perusahaan sangat di pengaruhi oleh kinerja individu karyawannya. Setiap perusahaan akan selalu berusaha untuk meningkatkan kinerja karyawan, dengan harapan apa yang menjadi tujuan perusahaan akan tercapai. Semakin baik kinerja karyawan maka semakin baik pula sebuah perusahaan.

PT. Candana Putra Nusantara adalah sebuah perusahaan yang mengelola kayu lapis yang terletak di Jl. Dusun Bubur, RT 10/RW 03 Desa Paras, Kecamatan Tegalsiwalan, kabupaten Probolinggo. Kinerja perusahaan dalam pembuatan kayu lapis belum sepenuhnya maksimal, hal ini dapat dilihat dari pencapaian yang masih belum memenuhi target. Data produksi dapat dilihat pada Tabel 1 berikut ini :

Tabel 1. Data Produksi PT. Candana Putra Nusantara Tahun 2016

\begin{tabular}{ccccc}
\hline Bulan & Target (Unit) & Realisasi (Unit) & \multicolumn{2}{c}{ Selisih } \\
\cline { 3 - 5 } & & & Unit & $(\%)$ \\
\hline Januari & 850 & 837 & 13 & $1,5 \%$ \\
Februari & 850 & 844 & 6 & $0,7 \%$ \\
Maret & 850 & 828 & 22 & $2,5 \%$ \\
April & 850 & 830 & 20 & $2,3 \%$ \\
Mei & 850 & 846 & 4 & $0,4 \%$ \\
Juni & 850 & 829 & 21 & $2,4 \%$ \\
Juli & 850 & 833 & 17 & $2 \%$ \\
Agustus & 850 & 831 & 19 & $2,2 \%$ \\
September & 850 & 829 & 21 & $2,4 \%$ \\
Oktober & 850 & 825 & 25 & $2,9 \%$ \\
November & 850 & 824 & 26 & $3 \%$ \\
Desember & 850 & 835 & 15 & $1,7 \%$ \\
\hline
\end{tabular}

Dilihat dari Tabel 1 tersebut, kinerja karyawan produksi PT. Candana Putra Nusantara pada tahun 2016 masih belum maksimal, dimana hasil produk yang dicapai oleh karyawan produksi masih belum mencapai target perusahaan. Hal ini ada beberapa permasalahan yang terjadi di dalam perusahaan PT. Candana Putra Nusantara yaitu pembayaran gaji yang masih dibawah UMK Probolinggo. 
Tabel 2. Data Gaji Karyawan Produksi PT. Candana Putra Nusantara Tahun 2016

\begin{tabular}{ccc}
\hline Bulan & Gaji yang diperoleh & UMK Probolinggo \\
\hline Januari & Rp. 1.550 .000 & Rp. 1.879 .220 \\
Februari & Rp. 1.550 .000 & Rp. 1.879 .220 \\
Maret & Rp. 1.550 .000 & Rp. 1.879 .220 \\
April & Rp. 1.550 .000 & Rp. 1.879 .220 \\
Mei & Rp. 1.550 .000 & Rp. 1.879 .220 \\
Juni & Rp. 1.550 .000 & Rp. 1.879 .220 \\
Juli & Rp. 1.550 .000 & Rp. 1.879 .220 \\
Agustus & Rp. 1.550 .000 & Rp. 1.879 .220 \\
September & Rp. 1.550 .000 & Rp. 1.879 .220 \\
Oktober & Rp. 1.550 .000 & Rp. 1.879 .220 \\
November & Rp. 1.550 .000 & Rp. 1.879 .220 \\
Desember & Rp. 1.550 .000 & Rp. 1.879 .220 \\
\hline
\end{tabular}

Dari Tabel 2 dapat diketahui bahwa pemberian gaji di PT. Candana Putra Nusantara masih di bawah UMK Probolinggo. Mangkunegara (2007:84) menyatakan bahwa kompensasi yang diberikan kepada pegawai sangat berpengaruh pada tingkat kepuasan kerja, motivasi kerja dan hasil kerja (kinerja karyawan). Selain itu, ada beberapa masalah disiplin kerja yaitu, rendahnya ketaatan karyawan dalam bekerja seperti , telat masuk setelah istirahat, pulang lebih cepat, masih adanya karyawan yang mengobrol saat bekerja dan absensi karyawan. berikut adalah tabel daftar presensi kehadiran karyawan bagian produksi PT. Candana Putra Nusantara.

Tabel 3. Presensi Karyawan Produksi pada Tahun 2016

\begin{tabular}{ccccc}
\hline Bulan & $\begin{array}{c}\text { Jumlah } \\
\text { Karyawan }\end{array}$ & $\begin{array}{c}\text { Absensi } \\
\text { karyawan } \\
\text { (Orang) }\end{array}$ & Keterangan & Persentase \\
\hline Januari & 100 & 8 & Alfa & $8 \%$ \\
Februari & 100 & 6 & Alfa & $6 \%$ \\
Maret & 100 & 6 & Alfa & $6 \%$ \\
April & 100 & 9 & Alfa & $9 \%$ \\
Mei & 100 & 7 & Alfa & $7 \%$ \\
Juni & 100 & 7 & Alfa & $7 \%$ \\
Juli & 100 & 6 & Alfa & $6 \%$ \\
Agustus & 100 & 8 & Alfa & $8 \%$ \\
September & 100 & 5 & Alfa & $5 \%$ \\
Oktober & 100 & 5 & Alfa & $5 \%$ \\
November & 100 & 7 & Alfa & $7 \%$ \\
Desember & 100 & 6 & Alfa & $6 \%$ \\
\hline
\end{tabular}

Dari Tabel 3 tersebut dapat diketahui bahwa tingkat absensi karyawan bagian produksi PT. Candana Putra Nusantara yang tidak masuk kerja tanpa disertai keterangan cukup tinggi pada tahun 2016. Adapun pendapat yang dikemukakan oleh Hasibuan (2012:193) menyatakan bahwa semakin baik disiplin kerja seorang karyawan, maka semakin tinggi hasil kinerja yang akan dicapai.

Realita kinerja karyawan PT. Candana Putra Nusantara dinilai masih belum optimal. Dimana terdapat permasalahan kinerja antara lain, target perusahaan yang masih belum dicapai oleh karyawan. Diduga Masalah belum optimalnya kinerja ini muncul karena terdapat 
beberapa masalah kompensasi dan juga disiplin kerja pada PT. Candana Putra Nusantara.

$$
\text { Penelitian ini mempunyai }
$$

rumusan masalah bagaimana deskripsi kinerja karawan PT. Candana Putra Nusantara, bagaimana deskripsi kompensasi PT. Candana Putra Nusantara dan bagaimana deskripsi disiplin kerja karyawan PT. Candana Putra Nusantara. Kemudian apakah kompensasi dan disiplin kerja berpengaruh terhadap kinerja karyawan PT. Candana Putra Nusantara dan variabel manakah yang paling dominan pengaruhnya dalam mempengaruhi kinerja karyawan PT. Candana Putra Nusantara.

Penelitian ini bertujuan untuk mendeskripsikan kinerja karawan PT. Candana Putra Nusantara, untuk deskripsikan kompensasi PT. Candana Putra Nusantara dan untuk mendeskripsikan disiplin kerja karyawan PT. Candana Putra Nusantara.

Selain itu, untuk mengetahui pengaruh kompensasi dan disiplin kerja terhadap kinerja karyawan PT. Candana Putra Nusantara dan untuk mengetahui variabel manakah yang paling dominan pengaruhnya dalam mempengaruhi kinerja karyawan PT. Candana Putra Nusantara.

\section{TINJAUAN PUSTAKA}

Kinerja adalah hasil kerja dari seseorang, baik secara kualitas ataupun kuantitas dalam menjalankan tugasnya sesuai dengan tanggung jawab yang di berikan (Mangkunegara, 2007:67).

Kompensasi adalah semua pendapatan yang berbentuk uang, barang langsung ataupun tidak langsung yang diterima oleh karyawan sebagai imbalan atas yang diberikan kepada perusahaan Hasibuan (2002:117).

Menurut Rivai (2009:825) disiplin kerja adalah suatu alat yang digunakan manajer untuk mengubah suatu perilaku serta sebagai suatu upaya untuk meningkatkan kesadaran dan kesediaan seseorang mentaati semua peraturan organisasi dan norma-norma sosial yang berlaku.

Hubungan antara kompensasi dan kinerja yaitu Salah satu cara manajemen untuk meningkatkatkan prestasi kerja, memotivasi dan meningkatkan kepuasan dan kinerja karyawan adalah melalui kompensasi (Mathis dan Jackson, 2000). Selain itu,

Hubungan antara kompensasi dan kinerja juga dijelaskan dalam teori pengharapan yang mengatakan bahwa seseorang akan mengeluarkan upaya-upaya tingkat tinggi untuk kinerjanya, apabila dengan tingkat kinerjanya yang tinggi diperoleh ganjaran (kompensasi) sesuai pengharapan (Robbins, 2001:189). Selain kompensasi, disiplin kerja juga dapat mempengaruhi kinerja karyawan. Adapun pendapat yang dikemukakan oleh Hasibuan

(2002:193) menyatakan bahwa semakin baik disiplin kerja seorang karyawan, maka semakin tinggi hasil kinerja yang akan dicapai.

Faktor- faktor yang mempengaruhi kinerja menurut Siagian (2002) menyatakan bahwa kinerja karyawan dipengaruhi beberapa faktor, yaitu : kompensasi, lingkungan kerja, budaya organisasi, kepemimpinan, motivasi kerja , 
disiplin kerja, kepuasan kerja, dan komunikasi.

Terdapat beberapa penelitian terdahulu yang mendasari penelitian ini yaitu Firziyanah (2014) yang menemukan bahwa kompensasi secara parsial berpengaruh terhadap kinerja karyawan, disiplin kerja secara parsial berpengaruh terhadap kinerja karyawan dan kompensasi dan disiplin kerja secara bersamasama berpengaruh terhadap kinerja karyawan PT. Gapura Omega Alpha Land. Arum, (2014) menemukan bahwa kompensasi kerja berpengaruh positif terhadap kinerja karyawan, disiplin kerja berpengaruh positif terhadap kinerja karyawan, lingkungan kerja berpengaruh positif terhadap kinerja karyawan. Secara bersama-sama kompensasi kerja, disiplin kerja dan lingkungan kerja berpengaruh signifikan terhadap kinerja karyawan CV. Metalindo Manunggal Karsa. Kompensasi yang paling kuat pengaruhnya terhadap kinerja karyawan.

Anissa (2017). Menemukan bahwa kompensasi kerja berpengaruh positif terhadap kinerja karyawan, disiplin Kerja berpengaruh terhadap kinerja karyawan, serta kompensasi sebagai variabel dominan dalam mempengaruhi kinerja karyawan PT. Tri Hasta Perkasa Jakarta.

Hasil penelitian yang dilakukan oleh Annisa Muzkholifah (2017) kompensasi dan disiplin kerja berpengaruh positif dan signifikan terhadap kinerja karyawan. Dari pendapat para ahli dan hasil penelitian terdahulu dapat di gambarkan kerangka pikir sebagai berikut.

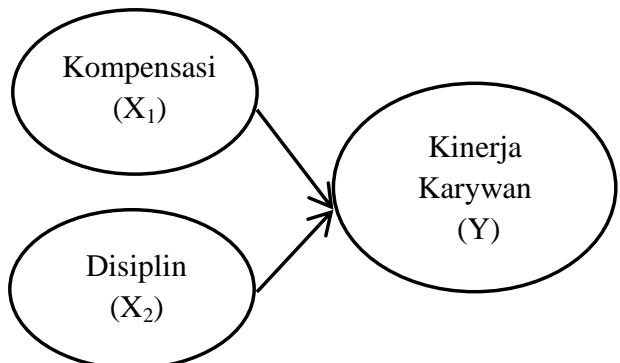

Gambar 1. Kerangka Pikir

Berdasarkan teori-teori yang di kemukakan oleh para ahli, serta adanya penelitian terdahulu yang telah di lakukan oleh peneliti-peneliti sebelumnya maka peneliti mengajukan hipotesis pada penelitian ini sebagai berikut. Hipotesis a1, diduga kompensasi dan disiplin kerja berpengaruh secara signifikan terhadap kinerja karyawan. Hipotesis a2, diduga kompensasi paling berpengaruh terhadap kinerja karyawan.

\section{METODE PENELITIAN}

Jenis penelitian ini adalah penelitian survey. Populasi dalam penelitian ini adalah seluruh individu yang masih aktif sebagai karyawan PT. Candana Putra Nusantara memiliki sekitar 100 Karyawan bagian produksi. Diketahui bahwa populasi 100 orang.

Menurut Sugiyono apabila populasi penelitian kurang dari 100 maka akan diambil semua sebagai sampel penelitian, namun apabila lebih maka dapat diambil sampel penelitian dengan menggunakan teknik sampling. Karena populasi penelitian 100 orang,maka peneliti menggunakan total sampling yaitu dengan mengambil semua populasi objek penelitian dengan jumlah 100 responden 
Jenis data yang digunakan adalah kuantitatif yang diperoleh dari jawaban kuesioner yang disebarkan kepada sejumlah responden. Sedangkan untuk menunjang pembahasan dalam penelitian ini maka sumber data yang digunakan adalah data primer dan data sekunder.

Metode pengumpulan data dalam penelitian ini adalah dengan menyebar kuesioner dan wawancara. Kemudian teknik analisa data menggunakan rentang skala dan analisis regresi linear berganda. Selain itu uji hipotesis dalam penelitian ini menggunkan uji $f$ dan uji t.

\section{HASIL DAN PEMBAHASAN}

Karakteristik responden dikelompokkan berdasarkan jenis kelamin, usia, pendidikan terakhir, masa kerja, status perkawinan, dan jumlah tanggungan. Hasil rentang skala variabel kinerja karyawan PT. Candana Putra Nusantara secara lengkap dapat di amati pada tabel berikut :

Tabel 4. Rentang Skala Variabel

\begin{tabular}{cccccccc}
\multicolumn{8}{c}{ Kinerja Karyawan (Y) } \\
\hline \multirow{2}{*}{ Item } & SS & $\mathrm{S}$ & $\mathrm{N}$ & $\mathrm{TS}$ & STS & Rentang & \multirow{2}{*}{ Ket } \\
& 5 & 4 & 3 & 2 & 1 & Skala & \\
\hline $\mathrm{Y}_{1}$ & 15 & 25 & 42 & 18 & 0 & 337 & Cukup \\
$\mathrm{Y}_{1}$ & 18 & 49 & 18 & 7 & 8 & 362 & Tinggi \\
$\mathrm{Y}_{1}$ & 22 & 27 & 30 & 5 & 16 & 334 & Cukup \\
& \multicolumn{7}{c}{ Rata-rata } \\
\hline
\end{tabular}

Pada Tabel 4 menunjukkan bahwa Secara keseluruhan, kinerja karyawan di PT. Candana Putra Nusantara adalah tinggi. Hal ini karena skor rata-rata rentang skala mencapai 344 yang termasuk dalam kategori tinggi. Oleh sebab itu, indikator kinerja karyawan yang tinggi ditunjukkan melalui kemampuan karyawan dalam menyelesaikan pekerjaan dengan baik. Hasil rentang skala kompensasi di PT. Candana Putra Nusantara secara lengkap dapat dilihat pada Tabel 5 berikut ini :

Tabel 5. Rentang skala variabel kompensasi (X1)

\begin{tabular}{cccccccc}
\hline Item & SS & S & N & TS & STS & Rentang & \multirow{2}{*}{ Ket } \\
& 5 & 4 & 3 & 2 & 1 & Skala & \\
\hline X1.1 & 12 & 17 & 12 & 26 & 33 & 249 & Rendah \\
X1.2 & 16 & 39 & 15 & 20 & 10 & 331 & Cukup \\
X1.3 & 29 & 52 & 14 & 5 & 0 & 405 & Tinggi \\
& & \multicolumn{7}{c}{ Rata-Rata } & & 328 & Cukup \\
\hline
\end{tabular}

Pada Tabel 5, menjelaskan bahwa variabel kompensasi masuk dalam kategori cukup, yaitu diperoleh skor rata-rata sebesar 328 . Hasil rata-rata tersebut menjelaskan bahwa pemenuhan kompensasi dipraktikan sesuai dengan ketentuan yang berlaku di PT. Candana Putra Nusantara. Kemudian, Hasil rentang skala disiplin kerja di PT. Candana Putra Nusantara dapat dilihat pada tabel sebagai berikut :

Tabel 6. Rentang Skala

Variabel Disiplin Kerja (X2)

\begin{tabular}{cccccccc}
\hline Item & SS & S & N & TS & STS & Rentang & \multirow{2}{*}{ Ket } \\
& 5 & 4 & 3 & 2 & 1 & Skala & \\
\hline $\mathrm{X} 2.1$ & 14 & 25 & 18 & 43 & 0 & 310 & Cukup \\
$\mathrm{X} 2.2$ & 12 & 17 & 12 & 26 & 33 & 249 & Rendah \\
$\mathrm{X} 2.3$ & 24 & 58 & 14 & 4 & 0 & 402 & Tinggi \\
& \multicolumn{7}{c}{ Rata-Rata } \\
\hline
\end{tabular}

Berdasarkan hasil analisis dapat diketahui bahwa disiplin kerja karyawan PT. Candana Putra Nusantara dalam kategori cukup yaitu diperoleh skor rata-rata sebesar 320. Hasil tersebut menunjukkan bahwa karyawan memiliki kedisplinan yang sesuai dengan peraturan yang berlaku di dalam perusahaan.

Hasil Analisis regresi linier berganda digunakan untuk 
mengetahui pengaruh kompensasi dan displin kerja terhadap kinerja karyawan di PT. Candana Putra Nusantara, dimana hasil penelitian telah diolah menggunakan program IBM SPSS STATISTIC $V 22$ dengan menggunakan hasil analisis regresi linier berganda (multiple regression) baik secara simultan dan parsial. Hasil analisis regresi linier berganda dapat dilihat pada tabel berikut:

Tabel 7. Rekapitulasi Analisis Regresi Linier Berganda

\begin{tabular}{cccc}
\hline Variabel & $\begin{array}{c}\text { Koefisien } \\
\text { Regresi }\end{array}$ & $\mathrm{t}_{\text {hitung }}$ & $\mathrm{Sig}$ \\
\hline $\mathrm{X}_{1}$ & 0,529 & 6,543 & 0,000 \\
$\mathrm{X}_{2}$ & 0,344 & 4,242 & 0,000 \\
Konstanta & $=1,457$ & \\
Adjusted $R$ & Square & $=0,522$ \\
Determinasi R & \multicolumn{2}{l}{$=0,532$} \\
\hline
\end{tabular}

Berdasarkan hasil analisis regresi, maka dapat dirumuskan suatu persamaan regresi berganda sebagai berikut, $\mathrm{Y}=1,457+0,529 \mathrm{X}_{1}$ $+0,344 \mathrm{X}_{2}+\mathrm{e} \cdot$ Berdasarkan hasil perhitungan analisis regresi linier berganda yang telah dilakukan menunjukkan kemampuan model dalam menjelaskan pengaruh variabel independent terhadap variabel dependent adalah besar, hal tersebut dapat dilihat pada nilai Adjusted $R$ Square $\left(\mathrm{R}^{2}\right)$ yaitu sebesar 0,522 .

Dengan demikian berarti bahwa model regresi yang digunakan mampu menjelaskan pengaruh variabel kompensasi dan displin kerja sebesar 52,2\% terhadap kinerja karyawan, sedangkan sisanya sebesar $47,8 \%$ dijelaskan oleh variabelvariabel lain yang tidak termasuk dalam penelitian ini.

Hasil analisis regresi linier berganda dari masing-masing variabel kompensasi dan disiplin kerja menunjukkan bahwa adanya korelasi berganda (R) sebesar 0,532.

Angka tersebut menunjukkan adanya hubungan yang cukup kuat antara variabel bebas terhadap variabel terkait. Yang bermakna bahwa pengaruh cukup kuat dari kompensasi dan displin kerja terhadap kinerja karywan di PT. Candana Putra Nusantara.

Untuk mengetahui apakah variabel independent secara simultan (bersama-sama) mempunyai pengaruh atau tidak terhadap variabel dependent, maka digunakan uji $\mathrm{F}$ (F-test), dengan membandingkan Fhitung dan Ftabel pada taraf nyata $5 \%(\alpha=0,05)$ atau perbandingan nilai signfikan $F$. Apabila Fhitung > Ftabel atau nilai Sig.F $<0,05$ berari Ho ditolak, sebaliknya ketika Fhitung < Ftabel atau nilai Sig.F > 0,05 berari Ho diterima. Pada penelitian ini, ftabel adalah 8,940. Adapun nilai fhitung tersaji pada gambar dibawah ini:

\begin{tabular}{ccc}
\multicolumn{3}{c}{ Tabel 8. Hasil Uji F } \\
\hline $\begin{array}{c}\text { Mean } \\
\text { square }\end{array}$ & $F$ & Sig. \\
\hline 127,640 & 55,147 & 0,000 \\
\hline
\end{tabular}

Berdasarkan Tabel 8, f hitung diperoleh sebesar 55,147. Sehingga dari perbandingan di atas dapat diketahui bahwa Fhitung > Ftabel $(55,147>8,940)$ sehingga Ho ditolak dan Ha diterima. Sedangkan nilai sig. f diketahui 0,00 yang lebih kecil dari taraf nyata $5 \%(0,00<0,05)$.

Demikian dapat dikatakan bahwa secara serentak variabel kompensasi dan displin kerja berpengaruh signifikan terhadap kinerja karyawan (Y) di PT. Candana Putra Nusantara. 
Untuk mengetahui pengaruh masing-masing variabel independent, yaitu variabel kompensasi dan disiplin kerja secara parsial terhadap kinerja karyawan di PT. Candana Putra Nusanatara, maka digunakan uji t (t- test). Dari hasil perhitungan parsial menunjukkan bahwa pada taraf nyata $5 \% \quad(\alpha=0,05)$ dengan tingkat kepercayaan $95 \%$ diperoleh nilai ttabel sebesar 1,984.

Dengan pengujian statistik diperoleh nilai thitung sebesar 6,543, karena nilai thitung $>$ ttabel $(6,543>$ $1,984)$, sedangkan sig. $\mathrm{f}<$ taraf nyata $5 \%(0,00<0,05)$, maka disimpulkan bahwa secara parsial variabel kompensasi (X1) berpengaruh signifikan terhadap kinerja karyawan di PT. Candana Putra Nusantara. Kemudian,

Dari hasil perhitungan parsial menunjukkan bahwa pada taraf nyata $5 \% \quad(\alpha=0,05) \quad$ dengan tingkat kepercayaan $95 \%$ diperoleh nilai ttabel sebesar 1,956. Dengan pengujian statistik diperoleh nilai thitung sebesar 4,242, karena nilai thitung $>$ ttabel $(4,242>1,984)$ dan sig. F < taraf nyata $5 \%(0,00<0,05)$, maka disimpulkan bahwa secara parsial variabel disiplin kerja (X2) berpengaruh signifikan terhadap kinerja karyawan.

Berdasarkan hasil pengujian $\mathrm{f}$ dan $t$ dapat dijelaskan bahwa variabel bebas mempengaruhi variabel terikat, baik secara simultan dan parsial. Kondisi ini menunjukkan bahwa hipotesis pertama diterima. Sehingga, dapat dibuktikan bahwa kompensasi dan displin kerja berpengaruh signifikan terhadap kinerja karyawan.

Adapun untuk mengetahui besarnya pengaruh variabel bebas terhadap variabel terikat maka dapat diketahui dari hasil perbandingan koefisien regresi masing-masing variabel. Standardized Coeficient Beta mampu mengeliminasi perbedaan unit ukuran pada variabel independent (bebas) yaitu variabel kompensasi dan disiplin kerja. Adapun nilai dari standardized coefficent Beta ditunjukkan oleh tabel sebagai berikut:

Tabel 9. Standardized Coeficient

\begin{tabular}{cc}
\multicolumn{2}{c}{ Beta } \\
\hline Variabel & $\begin{array}{c}\text { Standardized } \\
\text { Coeficient Beta }\end{array}$ \\
\hline Kompensasi (X1) & 0,513 \\
\hline Disiplin Kerja (X2) & 0,333 \\
\hline
\end{tabular}

Berdasarkan hasil koefisien regresi $(\beta)$ masing-masing variabel mempunyai pengaruh dominan terhadap kinerja karyawan di PT. Candana Putra Nusantara.

Akan tetapi, variabel yang paling dominan atau variabel yang paling kuat antara kompensasi, karena dapat dilihat pada nilai koefisien regresi yaitu variabel kompensasi sebesar 0.513 .

Nilai tersebut lebih besar jika dibandingkan nilai pada variabel displin kerja, yang mengakibatkan kompensasi menjadi variabel yang mendominasi pengaruh terhadap kinerja karyawan.

Hasil dari penelitian ini mendukung penelitian yang dilakukan oleh Anisa Mukholifah (2017) dan Arum Eka Murti (2014) yang menyimpulkan bahwa baik secara simultan dan parsial, kompensasi dan disiplin kerja berpengaruh terhadap kinerja karyawan. Selanjutnya,

Berdasarkan uji regresi linier berganda diperoleh kompensasi 
sebagai variabel yang dominan dibandingkan variabel yang lainnya terhadap kinerja karyawan. Hal ini dapat dilihat pada standardized coefficient Beta, yang mengungkapkan bahwa kompensasi memiliki peroleh nilai koefisien tertinggi dari nilai koefisien pada displin kerja.

Kondisi tersebut juga didukung oleh penelitian yang dilakukan oleh Anisa Mukholifah (2017), yang menyatakan kompensasi sebagai variabel paling berpengaruh untuk meningkatkan kinerja karyawan dibandingkan variabel disiplin kerja.

Hal ini dapat diartikan bahwa pemberian kompensasi merupakan faktor pendorong terdepan dalam menimbulkan kinerja karyawan. Karyawan akan menunjukkan performa kerja yang prima melalui kesesuain dan ketepatan gaji, upah lembur dan tunjangan. Sehingga, dapat dikatakan bahwa dorongan dari variabel pemberian kompensasi mampu meningkatkan kinerja karyawan.

\section{SIMPULAN}

Berdasarkan pembahasan hasil penelitian yang telah dilakukan tentang kompensasi dan disiplin kerja terhadap kinerja karyawan di PT. Candana Putra Nusantara. Maka dapat disimpulkan sebagai berikut: Hasil dari rentang skala Kinerja karyawan di PT. Candana Putra Nusantara termasuk dalam katagori tinggi dengan hasil nilai rata- rata sebesar 344.

Kompensasi tergolong dalam kategori cukup dengan hasil nilai rata rata sebesar 328. Selain itu, Disiplin kerja tergolong dalam kategori cukup, dengan skor rata- rata 320.
Hasil dari analisis regresi linear berganda Terdapat pengaruh signifikan antara kompensasi dan disiplin kerja terhadap kinerja karyawan di PT. Candana Putra Nusantara. Kompensasi paling berpengaruh terhadap kinerja karyawan di PT. Candana Putra Nusantara.

Berdasarkan hasil penelitian dan pembahasan dalam penelitian ini, maka peneliti memberikan saran yang bersifat membangun. Adapun saran yang diberikan dalam penelitian ini, sebagai berikut:

Perusahaan seharusnya dapat memperhatikan Kompensasi yang terbilang perlu ditingkatkan meskipun sudah dalam katagori cukup, dengan pemberian sesuai UMK Probolinggo. Peningkatan disiplin kerja meskipun sudah masuk dalam katagori cukup terutama pada ketaatan terhadap peraturan perusahaan.

Bagi peneliti selanjutkan dapat dijadikan sebagai acuan untuk mengembangkan penelitian ini dengan mempertimbangkan variabelvariabel lain diluar variabel-variabel dalam penelitian ini; seperti gaya kepemimpinan, beban kerja, kepuasan kerja, dan lain sebagainya.

\section{DAFTAR PUSTAKA}

Hasibuan, Malayu S. P. 2002. Manajemen Sumber Daya Manusia, Edisi Revisi. Jakarta: Bumi Aksara.

Hasibuan, Malayu S. P. 2012. Manajemen Sumber Daya Manusia, Edisi Revisi : Jakarta: Bumi Aksara.

Mangkunegara, A. P. 2006. Evaluasi Kinerja Sumber Daya Manusia. Jakarta: Refika Aditama. 
Mangkunegara, A. P. 2006. Perencanaan dan Pengembangan Sumber Daya Manusia (Cetakan Kedua). Bandung: PT. Refika Aditama

Mangkunegara, A. P. 2007. Manajemen Sumber Daya Manusia Perusahaan. Bandung: PT. Remaja Rosdakarya.

Mathis, Robert L, \& Jhon H. Jackson, 2000. Human Resource Management10th Edition, Tomson South-Western, United States.

Murti, Arum Eka. 2014. "Analisis Pengaruh Kompensasi Kerja, Disiplin Kerja dan Lingkungan Kerja Fisik terhadap Kinerja Pegawai Studi pada CV. Metalindo Manunggal Karsa". Semarang: Universitas Diponegoro

Muzholifah, Annisa. 2017. "Pengaruh Kompensasi dan Disiplin Kerja terhadap Kinerja Karyawan PT. Triharta Perkasa

Jakarta”. Perpustakaan Universitas Esa Unggul Rivai, Veithzal. 2009. Manajemen Sumber Daya Manusia Untuk Perusahaan Dari Teori ke Praktik. Jakarta: Raja Grafindo Persada

Robbins, Stephen P. 2001. Perilaku Organisasi, Edisi 8. Jakarta : Prentice Hall,

Siagian, Sondang P. 2002. Kiat Meningkatkan Produktivitas Kerja. Jakarta: Asdi Mahasatya. Sugiyono. 2015. Metode Penelitian Pendidikan (Pendekatan Kuantitatif, Kualitatif dan $R \& D)$. Bandung: Penerbit CV. Alfabeta.

Utami, Firziyanah Mustika. 2014. "Pengaruh Komepnsasi dan Disiplin Kerja terhadap Kinerja Karyawan (Studi pada PT. Gapura Omega Alpha Land, Depok)" . Jakarta : Universitas Islam Negeri Syarif Hidayatullah. 